\title{
Genetic parameters of growth traits in Nellore cattle ${ }^{1}$
}

\section{Parâmetros genéticos de características de crescimento de bovinos da raça Nelore}

\author{
Leandro Molina Kamei²; Edson Luis de Azambuja Ribeiro ${ }^{3}$; \\ Nilva Aparecida Nicolao Fonseca ${ }^{3}$; Carolina Amália de Souza Dantas Muniz ${ }^{3 *}$; \\ Tatiane Vito Camiloti'; Natália Albieri Koritiaki ${ }^{4}$; Ana Paula de Souza Fortaleza ${ }^{4}$
}

\begin{abstract}
This study evaluated non-genetic factors and calculated heritability estimates of direct and maternal effects for growth traits in Nellore cattle raised in southern Brazil. Performance records of 4170, 1538, 3139,1830 , and 1151 calves born from 2005 to 2011 were analyzed for birth weight (BW), adjusted120day weight (W120), adjusted 205-day weight (W205), adjusted365-day weight (W365), and adjusted 550-day weight (W550), respectively. The components of (co)variance used to calculate heritability estimates were determined by Derivative-Free Restricted Maximum Likelihood using the MTDFREML software. Contemporary groups were included in the model as fixed effects, and direct and maternal effects, permanent environmental effects, and residual errors were included as random effects. Phenotypic correlations were estimated using the PROC CORR procedure from SAS. Overall means for BW, W120, W205, W365, and W550 were 38, 138, 201, 270, and $376 \mathrm{~kg}$, respectively. Heritability estimates for direct and maternal effects were $0.17 \pm 0.04$ and $0.11 \pm 0.03(\mathrm{BW}), 0.14 \pm 0.03$ and $0.03 \pm 0.04(\mathrm{~W} 120)$, and $0.17 \pm 0.04$ and $0.09 \pm 0.03$ (W205). Genetic, phenotypic, and environmental correlations were 0.79 , 0.44 , and 0.32 for BW and W120, 0.79, 0.39, and 0.26 for BW and W205, and $0.96,0.74$, and 0.75 for $\mathrm{W} 120$ and W205. The results indicate that selection for pre-weaning weight would be more efficient using W205, and genetic correlation coefficients indicate that selection at any age should produce a positively correlated response at older ages. Genetic, phenotypic, and environmental correlation coefficients between W365 and W550 were $0.99,0.75$, and 0.76 , respectively. Selection for adjusted 550-day weight should produce the greatest genetic gains. Genetic correlation coefficients between weight traits indicate that selection for weight at older ages, which could help reduce the number of weighings and increase accuracy of selection at younger ages, produces gains at older ages.
\end{abstract}

Key words: Beef cattle. Body weight. Correlation. Direct heritability. Maternal heritability.

\section{Resumo}

Com o objetivo de estudar os fatores ambientais e estimar os parâmetros genéticos, para os efeitos diretos e maternos, para as características de crescimento, foram utilizadas 4170, 1538, 3139, 1830 e 1151 observações de peso ao nascer (PN), peso ajustado aos 120 dias de idade (P120), peso ajustado aos 205 dias de idade (P205), peso ajustado aos 365 dias de idade (P365) e peso ajustado aos 550 dias (P550), de bovinos da raça Nelore nascidos no período de 2005 a 2011 em uma propriedade situada no

\footnotetext{
${ }^{1}$ Parte da Dissertação de mestrado do primeiro autor no Programa de Pós-Graduação em Ciência Animal da Universidade Estadual de Londrina, UEL, Londrina, PR, Brasil.

2 Zootecnista, M.e, Programa em Ciência Animal, UEL, Londrina, PR, Brasil. E-mail: leandrokamei@hotmail.com

${ }^{3}$ Profs., Departamento de Zootecnia, UEL, Londrina, PR, Brasil. E-mail: elar@uel.br; nilvanf@hotmail.com; muniz@uel.br

${ }^{4}$ Zootecnistas, Dr ${ }^{\text {as }}$, Programa em Ciência Animal, UEL, Londrina, PR, Brasil. E-mail: tatianevito@hotmail.com; nataliaalbieri@ hotmail.com; anapaula fortaleza@yahoo.com

* Author for correspondence
} 
município de Amaporã-PR. As médias estimadas para PN, P120, P205, P365 e P550, foram 38 kg, 138 $\mathrm{kg}, 201 \mathrm{~kg}, 270 \mathrm{~kg}$ e $376 \mathrm{~kg}$, respectivamente. Os componentes de (co) variância utilizados para estimar as herdabilidades foram obtidos por meio do programa MTDFREML, o modelo utilizado considerou o efeito fixo do grupo de contemporâneos, o efeito da idade da vaca ao parto como covariável, além dos efeitos aleatórios genéticos aditivo direto e materno e o efeito de ambiente permanente. As correlações fenotípicas foram estimadas com o auxílio do procedimento PROC CORR do SAS. As herdabilidades estimadas para efeito genético direto e materno, respectivamente, para PN foram $0,17 \pm 0,04$ e $0,11 \pm$ 0,03, para P120 foram 0,14 $\pm 0,03$ e $0,03 \pm 0,04$, e para P205, 0,17 $\pm 0,04$ e $0,09 \pm 0,03, \mathrm{P} 365$ foram 0,14 e 0,02 , e para P550 foram 0,21 e 0,07. As correlações genéticas, fenotípicas e ambientais entre as características PN e P120 foram de 0,79, 0,44 e 0,32, entre PN e P205 foram 0,79, 0,39 e 0,26 e entre P120 e P205 foram 0,96, 0,74 e 0,75, respectivamente. Os resultados indicam que para o período prédesmama, a seleção por peso seria mais eficiente para P205 e o alto valor das correlações genéticas estimadas indicam que, ao selecionar os animais para qualquer uma das características, ocorrerá resposta correlacionada positivamente para as demais. As correlações genéticas, fenotípicas e ambientais entre as características P365 e P550 foram 0,99, 0,75 e 0,76. Para o período pós-desmama é possível obter maior ganho genético quando a seleção é feita aos 550 dias de idade, e devido à alta correlação genética entre as características, a seleção em qualquer idade promoverá mudança no mesmo sentido na outra.

Palavras-chave: Correlação. Herdabilidade direta. Herdabilidade materna. Gado de corte. Peso corporal.

\section{Introduction}

Weight is an important trait in beef cattle and several studies have evaluated birth weight and standardized weights at 120,205, 365, and 550 days to estimate finishing weight (AMARAL et al., 2014; ARAÚJO et al., 2014; FERREIRA et al., 2015; PASSAFARO et al., 2016). Birth weight plays an important role in a calf's ability to express its genetic potential, but should be monitored to prevent dystocia: in Nellore cows, calving ease is associated with moderately low birth weights $(30 \mathrm{~kg}$ on average) (HOLANDA et al., 2004; MENEZES et al., 2013; ARAÚJO et al., 2014). Calf weights at 120 days and 205 days (weaning weight) indicate a cow's producing ability, because maternal effects directly influence calf performance at these stages (CARDOSO et al., 2004). The postweaning period is important for genetic evaluation of beef cattle because it corresponds to the life cycle stages that best represents raising conditions, and suffers little influence from maternal effects (CARDOSO et al., 2004). Finally, yearling weight (550 days) is usually the last weight measurement taken by beef producers in conventional systems before finishing.

Genetic parameters are used to predict direct and correlated responses to selection, determine the genetic value of animals, and compute selection indexes (LIRA et al., 2013). Heritability measures the proportion of a trait controlled by genetic variation, and heritability estimates have been used to determine the best strategy for improving growth traits. Genetic correlations indicate the degree of association between two traits, helping predict how a trait is affected by changes in a correlated trait.

Several studies have reported low to moderate genetic additive heritability for pre-weaning weights (BOLIGON et al., 2011; LIRA et al., 2013; ARAÚJO et al., 2014; FERREIRA et al., 2015), high heritability for post-weaning weights (BOLIGON et al., 2008; LIRA et al., 2013; FERREIRA et al., 2015), and high positive genetic correlations between weights at different ages, with higher genetic correlations between adjacent weights, decreasing as the age difference increases (BOLIGON et al., 2009; GARNERO et al., 2010; PASSAFARO et al., 2016).These results indicate that direct selection can result in genetic gains. The characteristics of weight development in beef cattle are very important, as they reflect the growth curve of the animals, which is key to productivity increase in meat-producing systems. Thus, in this study, we estimated genetic parameters for birth weight and adjusted weights at $120,205,365$, and 550 days of age in a Nellore herd. 


\section{Materials and Methods}

The data used in this study were collected from a herd of Nellore cattle raised on pasture with mineral supplementation in a ranch located in Amaporã, northwest state of Paraná, southern Brazil.

Preweaning records of 4170, 1538, and 3139 calves born between 2005 and 2011 were analyzed for birth weight (BW), 120-day weight (W120), and 205-day weight (W205), respectively. Postweaning records of 1810 and 1151 calves born between 2005 and 2011 were analyzed for adjusted 365day weight (W365) and adjusted 550-day weight (W550), respectively.

Preliminary analysis was performed using Statistical Analysis System software (SAS Institute Inc., Cary, NJ, USA) to check for consistency of information and determine the model type for environmental effects. To estimate genetic parameters for calf weight traits, the contemporary group (CG) variable was created to group animals raised under similar conditions. Contemporary groups for birth weight included animals with the same sex born in the same year and Julian date for W120, W205, W550, and W365, CG included animals with the same sex born in the same year and season, and weighed on the same date. Two calving seasons were considered: spring-summer (September 23 to March 20) and autumn-winter (March 21 to September 22). Contemporary groups with less than three animals and bulls with less than two calves were removed from the analysis.

Phenotypic correlations between traits were estimated using the PROC CORR procedure from SAS (SAS Institute Inc.).

Estimates of (co)variance components and genetic parameters for growth traits were calculated using the MTDFREML software (BOLDMAN et al., 1995). The age at calving (linear and quadratic effects) was included in the model as a covariate and $\mathrm{CG}$ was included as a fixed effect. The covariance between maternal and direct effects was assumed zero, as suggested by Fries and Albuquerque (1998).
Each trait was analyzed separately for the estimation of variances and heritability values followed by bicharacter analysis is for the estimation of covariance matrices and genetic correlations between traits.

The general model used can be written as:

$$
y=X \beta+Z_{1} d+Z_{2} m+Z_{3} p+e, \text { with }\left(\mathrm{s}_{\mathrm{am}}\right)=0,
$$

where $\mathrm{y}=$ vector of weight records from a particular age; $X=$ incidence matrix relating each observation to each fixed effect; $\beta$ =fixed effects vector (contemporary groups); $Z_{1}=$ incidence matrix of direct additive genetic effects; $d=$ vector of direct additive genetic effects; $Z_{2}=$ incidence matrix of maternal additive genetic effects; $m=$ vector of maternal additive genetic effects; $Z_{3}=$ incidence matrix of permanent environmental effects; $\mathrm{p}=$ vector of permanent environmental effects; e = vector of non-observable random residuals, and ( $\left.\mathrm{s}_{\mathrm{am}}\right)$ $=$ covariance between direct and maternal genetic effects. Assuming $\mathrm{E}[\mathrm{y}]=\mathrm{X} \beta, \mathrm{E}[\mathrm{a}]=0, \mathrm{E}[\mathrm{m}]=0$, $\mathrm{E}[\mathrm{c}]=0$, and $\mathrm{E}[\mathrm{e}]=0$, the (co)variance matrix can be written as:

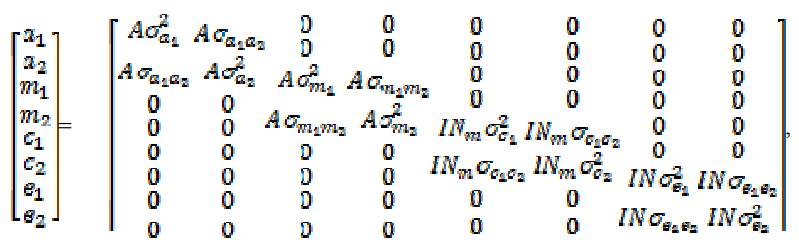

where $\mathrm{N}_{\mathrm{m}}=$ number of dams, $\mathrm{N}=$ number of observations, $\mathrm{A}=$ identity matrix. Covariances between the environmental effects of different animals were assumed zero.

\section{Results and Discussion}

Growth traits had higher mean values in our study (Table 1) than reported for Nellore cattle elsewhere. Average birth weights ranged from $29.5 \mathrm{~kg}$ to 32.8 $\mathrm{kg}$ in previous reports (HOLANDA et al., 2004; MENEZES et al., 2013; ARAÚJO et al., 2014), for Nellore herds in Midwestern and Northeastern Brazil, compared to $37.6 \mathrm{~kg}$ in this study. The same was true for the adjusted 120-day weight $138.4 \mathrm{~kg}$, 
compared to $119.1-129.0 \mathrm{~kg}$ in (BOLIGON et al., 2008; GARNERO et al., 2010; SOUZA et al., 2011), for the adjusted 205-day weight compare Table 1 to (BOLIGON, 2008; SANTOS et al., 2012; AMARAL et al., 2014; ARAÚJO et al., 2014), and for adjusted 365-day and 550-day weights, compare Table 1 with the study by (RIBEIRO et al., 2001; BOLIGON et al., 2008; GARNERO et al., 2010). The high birth weight measured in this study might result from the selection criteria adopted for the analysis, which included birth weight in the calculations of adjusted weights at weaning. In addition, the higher 365-day and 550-day weights observed here could be due to the intense selection for weight traits practiced at the ranch, which included periodic culling of animals not meeting performance expectations. Overall, though, the higher mean weight at all life cycle stages may result from the good pasture condition and the selection for calf weight traits practiced at the ranch since 1944. It should be noted that calves with high birth weight are more prone to dystocia, affecting calf survival, whereas animals with higher adult weights have greater maintenance and production requirements, which may be incompatible with pasture-based production systems with low nutrient content (CUNDIFF et al., 1984). On the other hand, the weaning weight at 205 days of age is an important trait in selection programs, because it is an estimate of the milking and mothering abilities of the dam and the growth potential of the calf (MALHADO et al., 2005). In addition, weaning weight is important in production system because preweaning gains have lower costs than postweaning gains (SANTOS et al., 2012).

Table 1. Number of observations $(\mathrm{N})$, mean values ( \pm standard deviation), coefficient of variation $(\mathrm{CV})$, and range (minimum-maximum values) for birth weight (BW) and weights adjusted to 120 days (W120), 205 days (W205), 365 days (W365), and 550 days (W550) in Nellore calves raised in southern Brazil.

\begin{tabular}{lcccc}
\hline Variable & $\mathrm{N}$ & Mean \pm SD & CV & Range (min-max) \\
\hline BW & 4170 & $37.53 \pm 5.04$ & 12.31 & $20.0-61.0$ \\
W120 & 1538 & $138.43 \pm 18.59$ & 11.1 & $71.0-209.0$ \\
W205 & 3139 & $200.77 \pm 29.63$ & 11.56 & $86.0-336.0$ \\
W365 & 1830 & $270.5 \pm 38.05$ & 8.9 & $164.0-406.0$ \\
W550 & 1151 & $376.05 \pm 58.28$ & 8.2 & $233.0-636.0$ \\
\hline
\end{tabular}

All calf weight traits measured had considerable direct additive genetic variability (Table 2), and thus can be used in breeding programs for selection for birth weight. The direct birth weight heritability estimate recorded here $(0.17)$ was similar to that reported by Holanda et al. (2004) (0.22) and Silveira et al. (2004) (0.17), but lower than those reported by Boligon et al. (2009), Araújo et al. (2014), and Pedrosa et al. (2014), which ranged 0.25-0.37. For 120-day weight, the direct heritability estimate (0.14) was below that reported in other Nellore cattle studies (SIQUEIRA et al., 2003; YOKOO et al., 2007; LIRA et al., 2013; FERREIRA et al., 2015). However, for the adjusted weaning weight (205 days of age), the direct heritability estimate (0.17) was comparable to values reported by Amaral et al. (2014) (0.19) and Silveira et al. (2004) (0.17), although lower than values recorded by Boligon et al. (2008), Lopes et al. (2008), Araújo et al. (2014), and Ferreira et al. (2015). The adjusted weight at 210 days of age was lower than the value reported by Lira et al. (2013). There was also a large difference in the365-day weight direct heritability estimate in this study (0.14) and those reported in five other studies (0.24-0.37, reported by GARNERO et al., 2010; AMARAL et al., 2014; ARAÚJO et al., 2014; FERREIRA et al., 2015). Finally, for 550-day weight, a heritability estimate similar to this study (0.21) was reported by Laureano et al. (2011) and Amaral et al. (2014) (0.18), whereas Garnero et al. (2010) and Ferreira et al. (2015) reported higher estimates ( 0.42 and 0.43 , respectively). 
Table 2. Estimates of variance components and genetic parameters for birth weight (BW) and weights adjusted to 120 days (W120), 205 days (W205), 365 days (W365), and 550 days (W550) in Nellore calves raised in southern Brazil.

\begin{tabular}{lccccc}
\hline Estimate & BW & W120 & W205 & W365 & W550 \\
\hline$\sigma^{2}{ }^{2}$ & 3.53 & 32.39 & 95.32 & 81.60 & 207.12 \\
$\sigma^{2}{ }^{2}$ & 2.25 & 6.40 & 49.00 & 11.17 & 64.15 \\
$\sigma^{2}{ }^{2}$ & 0.20 & 32.46 & 157.37 & 80.34 & 28.36 \\
$\sigma^{2}{ }^{2}$ & 15.29 & 168.21 & 362.44 & 422.78 & 670.25 \\
$\sigma^{2}{ }^{2}$ & 21.27 & 239.47 & 564.03 & 595.89 & 969.87 \\
$\mathrm{~h}^{2}{ }^{a}$ & $0.17 \pm 0.04$ & $0.14 \pm 0.03$ & $0.17 \pm 0.04$ & $0.14 \pm 0.05$ & $0.21 \pm 0.08$ \\
$\mathrm{~h}^{2}{ }^{2}$ & $0.11 \pm 0.03$ & $0.03 \pm 0.04$ & $0.09 \pm 0.03$ & $0.02 \pm 0.03$ & $0.07 \pm 0.05$ \\
\hline
\end{tabular}

$\sigma^{2}=$ variance $(\mathrm{a}=$ direct additive genetic effects; $\mathrm{m}=$ maternal genetic effects; $\mathrm{pe}=$ permanent environmental effects; $\mathrm{e}=$ residual effects; $\mathrm{p}=$ phenotypic effects $) ; \mathrm{h}^{2}=$ heritability $(\mathrm{a}=$ direct; $\mathrm{m}=$ maternal $)$.

Maternal heritability estimates (Table 2) indicate that maternal effects on calves were largest for birth weight, 120 day weight and 205-dayweight. In fact, up to weaning age, the calf is more dependent on its dam's milk than on feed. Marcondes et al. (2000), Holanda et al. (2004), and Araújo et al. (2014) reported maternal heritability estimates for birth weight (0.09-0.11) similar to this study (0.11). Similarly, the maternal heritability estimate for 205day weight (0.09) was comparable to those reported by Holanda et al. (2004), Silveira et al. (2004), and Laureano et al. (2011) for weaning weight, which was 0.08. According to Passafaro et al. (2016), even though maternal effects explain only a small proportion of the phenotypic variation, they should be included in models for analysis of weight data in cattle, because their removal may result in overestimation of heritability estimates and changes in breeding values. The maternal heritability estimates for 365-day (0.02) and 550-day (0.07) weights were low (Table 2). Nevertheless, direct selection for these traits may result in genetic gains. In fact, according to Meyer et al. (1991), maternal effects influence postweaning growth traits, and should be included in models for the estimation of genetic parameters of growth traits.

Genetic correlations between weights at different ages were high (Table 3), suggesting that animals that are genetically superior at a given age may keep that superiority at subsequent ages, especially after weaning. Moreover, selection for weight at any age should produce changes in the same direction at older ages. Boligon et al. (2009) and Passafaro et al. (2016) also found medium to high genetic correlations for weights at different ages and, in general, correlation coefficients were higher between adjacent weights. Estimating genetic correlations for weight at both young and adult ages is important because response to selection in adult weight, which has long been practiced in beef cattle, would be higher for higher weights at younger ages. Our results reinforce the prevailing concern with mature size of beef cows, because of the negative - although weak - correlation between adult weight and reproductive performance.

Table 3. Estimates of genetic, phenotypic, and environmental correlations for birth weight (BW) and weights adjusted to 120 days (W120), 205 days (W205), 365 days (W365), and 550 days (W550) in Nellore calves raised in southern Brazil.

\begin{tabular}{lccc}
\hline Traits & Genetic & Correlation & \\
BW-W120 & 0.79 & Phenotypic & Environmental \\
BW-W205 & 0.79 & 0.44 & 0.32 \\
W120-W205 & 0.96 & 0.39 & 0.26 \\
W365-W550 & 0.99 & 0.74 & 0.75 \\
\hline
\end{tabular}


Phenotypic correlations (Table 3) also suggest that calves that are heavier at young ages should also be heavier at older ages.

Moderate environmental correlations of birth weight with120-day weight (0.32) and with 205-day weight (0.26), and the high correlation coefficient between 120-day and 205-day weights (0.75) suggest an association between environmental factors and calf weights at 120 and 205 days of age. Thus, variation in a trait caused by non genetic factors will result in changes to other traits.

The genetic, phenotypic, and environmental correlations between 365-day and 550-day weights were also high (Table 3), indicating that most genes that affect calf weight at 365 days of age also affect calf weight at 550 days of age, as observed for nongenetic factors. Thus, heavier animals at 365 days of age should also be heavier at 550 days of age, which could help reduce the number of weighings and increase accuracy of selection at younger ages.

\section{Conclusions}

Birth weight was higher than in other studies of Nellore cattle, indicating that beef producers in the ranch should take special care with this trait to prevent calving-related losses.

The high heritability estimate indicates that selection for adjusted 550-day weights could produce the greatest genetic gains.

Genetic correlation coefficients between weight traits indicate that selection for weight at a specific age produces gains at older ages, which could help reduce the number of weighings and increase accuracy of selection at younger ages.

\section{References}

AMARAL, R. S.; CARNEIRO, P. L. S.; MARTINS FILHO, R.; AMBROSINI, D. P.; MALHADO, C. H. M. Tendências, parâmetros fenotípicos e genétios de características de crescimento em bovinos Nelore mocho do Nordeste brasileiro. Revista Brasileira de Saúde e Produção Animal, Salvador, v. 15, n. 2, p. 261-271, 2014.
ARAÚJO, C. V.; LÔBO, R. B.; FIGUEIREDO, L. G. G.; MOUSQUER, C. F.; LAUREANO, M. M. M.; BITTENCOURT, T. C. B. S. C.; ARAÚJO, S. I. Estimate of genetic parameters of growth traits of Nellore cattle in the Midwest region of Brazil. Revista Brasileira de Saúde e Produção Animal, Salvador, v. 15, n. 4, p. 846853, 2014.

BOLDMAN, K. G.; KRIESE, L. A.; VAN VLECK, L. D. A manual for use MTDFREML. Clay Center; Nebraska: USDA-ARS, $1995.120 \mathrm{p}$.

BOLIGON, A. A.; ALBURQUERQUE, L. G.; MERCADANTE, M. E. Z.; LÔBO, R. B. Herdabilidades e correlações entre pesos do nascimento à idade adulta em rebanhos da raça Nelore. Revista Brasileira de Zootecnia, Viçosa, MG, v. 38, n. 12, p. 2320-2326, 2009.

BOLIGON, A. A.; AlBUQUERQUE, L. G.; RORATO, P. R. N. Associações genéticas entre pesos e características reprodutivas em rebanho da Raça Nelore. Revista Brasileira de Zootecnia, Viçosa, MG, v. 37, n. 4, p. 596-601, 2008

BOLIGON, A. A.; BALDI, F.; ALBUQUERQUE, L. G. Genetic parameters and relationships between growth traits and scrotal circunference measure at differents ages in Nellore Cattle. Genetic and Molecular Biology, Ribeirão Preto, v. 34, n. 2, p. 225-230, 2011.

CARDOSO, F. F.; CARDELLINO, R. A.; CAMPOS, L. T. Componentes de co (variância) e parâmetros genéticos para características de caracteres pós-desmama em bovinos da raça Angus. Revista Brasileira de Zootecnia, Viçosa, MG, v. 33, n. 2, p. 313-319, 2004.

CUNDIFF, L. V.; KOCH, R. M.; GREGORY, K. E. Characterization of biological types of cattle (Cycle III) IV. Postweaning growth and feed efficiency. Journal of Animal Science, Cambridge, v. 58, n. 2, p. 312-323, 1984.

FERREIRA, F. L.; LOPES, F. B.; PEREIRA, L. S.; NEPOMUCENO, L. L.; GARCIA, J. A. S.; LÔBO, R. B.; SAINZ, R. D. Estimation of (co)variances for growth traits in Nellore cattle raised in the Humid Tropics of Brazil by random regression. Semina: Ciências Agrárias, Londrina, v. 36, n. 3, p. 1713-1724, 2015.

FRIES, L. A.; ALBUQUERQUE, L. G. Pressuposições e restrições dos modelos animais com efeitos maternos em gado de corte. In: PARANHOS da COSTA, M. J. R.; COMBERG, V. U. Comportamento materno em mamíferos: bases teóricas e aplicações aos ruminantes domésticos. São Paulo: Ed. Sociedade Brasileira de Etologia, 1998. p. 179-213.

GARNERO,A.V.; MUÑOZ, M.C.C.D.; MARCONDES, C. R.; LÔBO, R. B.; LIRA, T.; GUNSKI, R. J. Estimação de parâmetros genéticos entre pesos pré e pós-desmama 
na raça Nelore. Archivos de Zootecnia, Córdoba, v. 59, n. 226, p. 307-310, 2010.

HOLANDA, M. C. R.; BARBOSA, S. B. P.; RIBEIRO, A. C.; SANTORO, K. R. Tendências genéticas para crescimento em bovinos Nelore em Pernambuco, Brasil. Archivos de Zootecnia, Córdoba, v. 53, n. 202, p. 185194, 2004.

LAUREANO, M. M. M.; BOLIGON, A. A.; COSTA, R. B.; FORNI, S.; SEVERO, J. L. P.; ALBUQUERQUE, L. G. Estimativas de herdabilidade e tendências genéticas para características de crescimento e reprodutivas em bovinos da raça Nelore. Arquivos Brasileiros de Medicina Veterinária e Zootecnia, Belo Horizonte, v. 63, n. 1, p. 143-152, 2011.

LIRA, T. S.; PEREIRA, L. S.; LOPES, F. B.; FERREIRA, J. L.; LÔBO, R. B.; SANTOS, G. C. J. Genetic trends for growth traits in Nellore cattle raised in the umid Tropical region of Brazil. Ciência Animal Brasileira, Goiânia, v. 14, n. 1, p. 23-31, 2013.

LOPES, J. S.; RORATO, P. R. N.; WEBER, T.; BOLIGON, A. A.; COMIN, J. G.; DORNELLES, M. A. Efeito da interação genótipo $\mathrm{x}$ ambiente sobre o peso ao nascimento, aos 205 e aos 550 dias de idade de bovinos da raça Nelore na região Sul do Brasil. Revista Brasileira de Zootecnia, Viçosa, MG, v. 37, n. 1, p. 54-60, 2008.

MALHADO, C. H. M.; CARNEIRO, P. L. S.; MARTINS FILHO, R.; AZEVÊDO, D. M. M. R.; FACÓ, O.; MACHADO, C. H.; PICCINI, A. Tendência e parâmetros genéticos para o peso aos 205 dias de idade em bovinos da raça Nelore Mocho no Estado da Bahia. Revista Científica de Produção Animal, Teresina, v. 7, n. 2, p. 28-34, 2005.

MARCONDES, C. R.; BERGMANN, J. A. G.; ELER, J. P. ; FERRAZ, J. B. S.; PEREIRA, J. C. C.; PENNA, V. M. Análise de alguns critérios de seleção para características de crescimento na raça Nelore. Arquivo Brasileiro de Medicina Veterinária e Zootecnia, Belo Horizonte, v. 52, n. 1, p. 83-89, 2000.

MENEZES, L. M.; PEDROSA, A. C.; PEDROSO, D.; FERNANDES, S. Desempenho de bovinos Nelore e cruzados Blonde d'Aquitaine x Nelore do nascimento ao desmame. Revista Brasileira de Saúde e Produção Animal, Salvador, v. 14, n. 1, p. 177-184, 2013.

MEYER, K.; HAMMOND, K.; MACKINNON, J.; PAMELL, P. F. Estimates of covariances between reproduction and growth in Australian beef cattle. Journal of Animal Science, Cambridge, v. 69, n. 9, p. 3533-3543, 1991.
PASSAFARO, T. L.; FRAGOMENI, B. O.; GONÇALVES, D. R.; MORAES, M. M.; TORAL, F. F. B. Análise genética do peso em um rebanho de bovinos Nelore. Pesquisa Agropecuária Brasileira, Brasília, v. 51, n. 2, p. 149-158, 2016.

PEDROSA, V. B.; ELER, J. P.; FERRAZ, J. B. S.; PINTO, L. F. B. Utilização de modelos unicaracterística e multicaracterística na estimação de parâmetros genéticos na raça Nelore. Arquivo Brasileiro de Medicina Veterinária e Zootecnia, Belo Horizonte, v. 66, n. 6, p. 1802-1812, 2014.

RIBEIRO, M. N.; PIMENTA FILHO, E. C.; MARTINS, G. A.; SARMENTO, J. L. R.; MARTINS FILHO, R. Herdabilidade para efeitos direto e materno de características de crescimento de bovinos Nelore no Estado da Paraíba. Revista Brasileira de Zootecnia, Viçosa, MG, v. 30, n. 4, p. 1224-1227, 2001.

SANTOS, G. C. J.; LOPES, F. B.; MARQUES, E. G.; SILVA, M. C.; CAVALCANTE, T. V.; FERREIRA, J. L. Tendência genética para pesos padronizados aos 205, 365 e 550 dias de idade de bovinos Nelore da região norte do Brasil. Acta Scientiarum, Maringá, v. 34, n. 1, p. 97-101, 2012.

SILVEIRA, J. C.; MCMANUS, C.; MASCIOLI, A. S.; SILVA, L. O. C.; SILVEIRA, A. C.; GARCIA, J. A. S.; LOUVANDINI, H. Fatores ambientais e genéticos para características produtivas e reprodutivas em um rebanho Nelore no Estado do Mato Grosso do Sul. Revista Brasileira de Zootecnia, Viçosa, MG, v. 33, n. 6, p. 14321444, 2004.

SIQUEIRA, R. L. P. G.; OLIVEIRA, J. O.; LÔBO, R. B.; BEZERRA, L. A. F.; TONHATI, H. Análise da variabilidade genética aditiva de características de crescimento na Raça Nelore. Revista Brasileira de Zootecnia, Viçosa, MG, 32, n. 1, p. 99-105, 2003.

SOUZA, F. C.; SILVA, L. O. C.; GONDO, A.; FREITAS, J. A.; MALHADO, C. H. M.; FERRAR FILHO, P. B. F.; SERENO, J. R. B.; WEABER, R. L.; LAMBERSON, W. R. Parâmetros e tendência genética de peso de bovinos criados à pasto no Brasil. Archivos de Zootecnia, Córdoba, v. 60, n. 231, p. 457-465, 2011.

YOKOO, M. J. I.; ALBUQUERQUE, L. G.; LÔBO, R. B.; SAINZ, R. D.; CARNEIRO JÚNIOR, J. M.; BEZERRA, L. A. F.; ARAUJO, F. R. C. Estimativas de parâmetros genéticos para altura do posterior, peso e circunferência escrotal em bovinos da raça Nelore. Revista Brasileira de Zootecnia, Viçosa, MG, v. 36, n. 6, p. 1761-1768, 2007. 
